\title{
Neonatal small left colon syndrome (NSLCS): Rare but important complication in an infant of diabetic mother
}

\author{
Katherine Wood, ${ }^{1}$ Avinash Jinadatha, ${ }^{2}$ Kanupriya Agrawal, ${ }^{2}$ Sankara Narayanan ${ }^{2}$
}

'Oxford Newborn Care Unit, John Radcliffe Hospital, Oxford, United Kingdowm

${ }^{2}$ Woodland Neonatal Unit, West Hertfordshire Hospitals NHS Trust, Watford, UK

\section{Correspondence to} Dr Sankara Narayanan, cnarayanan@nhs.net

Accepted 18 December 2017

To cite: Wood K,
Jinadatha A, Agrawal K, et al.
BMJ Case Rep Published
Online First: [please
include Day Month Year].
doi:10.1136/bcr-2017-
223456

\section{DESCRIPTION}

A female infant born at $35+6$ weeks by caesarean section to a mother with poorly controlled type 1 diabetes was admitted to the neonatal unit due to hypoglycaemia. Birth weight was $3.2 \mathrm{~kg}$ (91-98th centile). On day 1 , the baby required a glucose load of $10 \mathrm{mg} / \mathrm{kg} / \mathrm{min}$ to maintain normoglycaemia. By day 2, her blood sugar levels stabilised, feeds were started and intravenous fluids were weaned. With the introduction of feeds, she had milky vomits and abdominal distension. Feeds were stopped and an abdominal X-ray showed a dilated transverse colon with an abrupt transition zone at splenic flexure (figure 1, arrow indicates transition zone). Symptoms resolved after passage of a large, thick plug of mucus and meconium that resembled an intestinal cast (figure 2).

Feeds were introduced and tolerated without any subsequent problems. Cystic fibrosis mutation testing was negative. A diagnosis of neonatal small left colon syndrome (NSLCS) was made based on clinical and radiological findings.

NSLCS is a rare functional lower intestinal disorder, first described in $1974 .^{12}$ The underlying pathogenesis is unknown, but there is a strong association with maternal diabetes. ${ }^{2}$ Transient dysmotility

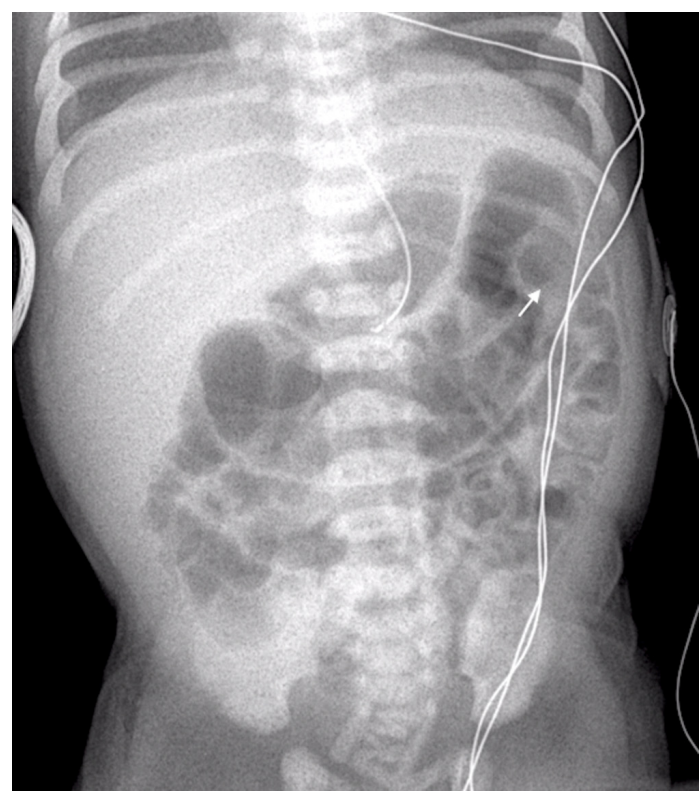

Figure 1 Patient's plain abdominal X-ray. There is a dilated transverse colon and calibre change at the splenic flexure indicates a transition point (arrow) and a relatively narrow left colon.

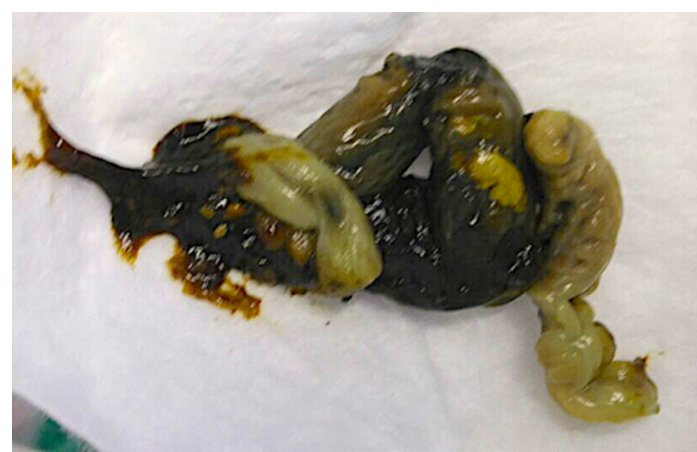

Figure 2 Patient's stool. This shows a thick plug of stool consisting of mucus and meconium in the form of an intestinal cast with imprint of mucosal folds.

of the descending colon leads to distinctive radiological features of a narrow descending colon with an abrupt transition zone at the splenic flexure. This can be visualised on plain abdominal X-rays as

\section{Patient's perspective}

My baby had prolonged admission in the neonatal unit and I believe some of her problems were related to my diabetes. I was very worried when she was 2 days old, when doctors informed me that she has bowel obstruction and possibly might need transfer to a surgical unit. However, doctors suspected this rare association with diabetes where the tail end of the bowel is not well formed in the baby and this was picked up on X-ray. She soon passed a horrible looking poo which looked like her bowels had come out, but after that her vomiting settled and she started tolerating feeds. I think it is important to consider this complication early on in this setting so that unnecessary transfers could be avoided.

\section{Learning points}

- Infants of diabetic mothers frequently have gastrointestinal symptoms that mimic intestinal obstruction.

- Neonatal small left colon syndrome is rare but an important differential in this situation and radiological findings are diagnostic.

- Early suspicion of this diagnosis averts unnecessary invasive interventions and surgery. 


\section{Images in...}

well as with contrast enema. Contrast enema when performed can be therapeutic, causing the passage of a meconium plug with the contrast. Normally there are no long-term complications and there is normal intestinal motility once resolved. ${ }^{23}$

Contributors KW wrote the manuscript. AJ and SN edited the manuscript. KA provided radiology input and reported X-ray.

Competing interests None declared.

Patient consent Guardian consent obtained.

Provenance and peer review Not commissioned; externally peer reviewed. (c) BMJ Publishing Group Ltd (unless otherwise stated in the text of the article) 2018. All rights reserved. No commercial use is permitted unless otherwise expressly granted.

\section{REFERENCES}

1 Davis WS, Allen RP, Favara BE, et al. Neonatal small left colon syndrome. Am J Roentgenol Radium Ther Nucl Med 1974;120:322-9.

2 Ellis H, Kumar R, Kostyrka B. Neonatal small left colon syndrome in the offspring of diabetic mothers-an analysis of 105 children. J Pediatr Surg 2009;44:2343-6.

3 Loening-Baucke V, Kimura K. Failure to pass meconium: diagnosing neonatal intestinal obstruction. Am Fam Physician 1999;60:2043-50.

Copyright 2017 BMJ Publishing Group. All rights reserved. For permission to reuse any of this content visit

http://group.bmj.com/group/rights-licensing/permissions.

BMJ Case Report Fellows may re-use this article for personal use and teaching without any further permission.

Become a Fellow of BMJ Case Reports today and you can:

- Submit as many cases as you like

- Enjoy fast sympathetic peer review and rapid publication of accepted articles

- Access all the published articles

Re-use any of the published material for personal use and teaching without further permission

For information on Institutional Fellowships contact consortiasales@bmjgroup.com

Visit casereports.bmj.com for more articles like this and to become a Fellow 